\title{
Antioxidant activity of twenty wild Spanish Thymus mastichina L. populations and its relation with their chemical composition
}

\author{
Teresa Delgado $^{\mathrm{a}}$, Pilar Marinero ${ }^{\mathrm{b}}$, M. Carmen Asensio-S.-Manzanera ${ }^{\mathrm{b}}$, Carmen Asensio ${ }^{\mathrm{b}}$, \\ Baudilio Herrero ${ }^{c}$, José Alberto Pereira ${ }^{a}$, Elsa Ramalhosa ${ }^{a, *}$ \\ ${ }^{a}$ CIMO, School of Agriculture, Polytechnic Institute of Bragança, Campus de Santa Apolónia, Apartado 1172, 5301-854 Bragança, Portugal \\ ${ }^{\mathrm{b}}$ Instituto Tecnológico Agrario de Castilla y León, Ctra. de Burgos Km.119, 47071 Valladolid, Spain \\ ${ }^{c}$ Universidad de Valladolid, Escuela Técnica Superior de Ingenierías Agrarias - Campus "La Yutera", Avda. Madrid 44, 34004 Palencia, Spain
}

\section{A R T I C L E I N F O}

\section{Article history:}

Received 2 July 2011

Received in revised form

27 December 2013

Accepted 28 December 2013

\section{Keywords:}

Thymus mastichina L.

Methanolic extracts

Essential oils

Antioxidant activity

Chemical composition

\begin{abstract}
A B S T R A C T
The antioxidant activity and chemical composition of essential oils and methanolic extracts of twenty Spanish Thymus mastichina L. populations were studied. Both essential oils and methanolic extracts possessed antioxidant properties. However, the total phenol contents of the methanolic extracts varied between 2.90 and $9.15 \mathrm{mg} \mathrm{GAE} / \mathrm{g}_{\text {extract }}$ and the $\mathrm{EC}_{25}$ values of $\mathrm{DPPH}$ free radical scavenging activity between 0.90 and $3.45 \mathrm{mg} / \mathrm{mL}$ for the methanolic extracts and $78-241 \mathrm{mg} / \mathrm{mL}$ for essential oils, these showing low antioxidant potential. Actually, in essential oils the main compound determined was the 1,8-cineole (56.8-69.6\%), whereas thymol, $\gamma$-terpinene, terpinolene and geraniol (species with considerable DPPH scavenging activity) were observed in low amounts. Concerning methanolic extracts, rosmarinic acid was the most abundant polyphenol $(1.70-9.85 \mathrm{mg} / \mathrm{g})$, followed by methoxysalicylic acid, apigenin, kaempferol and luteolin.
\end{abstract}

(c) 2014 Elsevier Ltd. All rights reserved.

\section{Introduction}

The species of Thymus genus are herbaceous perennial shrubs, commonly used as spices and/or medicinal herbs, with several pharmacological properties, such as antispasmodic, antiseptic, antitussive, expectorant and flatulence-reducing actions (Evans, 1998). Thyme oils are also used in dietary supplementation, as well as in the development of health products, particularly pharmaceuticals. Several studies over the antimicrobial activity of Thymus essential oils have shown their potential against important pathogenic microorganisms, such as Staphylococcus aureus (Bounatirou et al., 2007; Rasooli \& Mirmostafa, 2002), Helicobacter pylori (Hazzit, Baaliouamer, Veríssimo, Faleiro, \& Miguel, 2009) and Candida albicans (Faleiro et al., 2003; Hazzit et al., 2009), suggesting their ability in foodborne pathogens control.

Some species of Thymus are endemic in Iberian Peninsula, such as Thymus mastichina. The composition of essential oils of this specie had only been studied in Portuguese plants (Salgueiro et al.,

\footnotetext{
* Corresponding author. Tel.: +351 273 303308; fax: +351 273325405.

E-mail addresses: teresadelgado86@hotmail.com (T. Delgado), mardiepi@jcyl.es (P. Marinero), asesanmr@itacyl.es (M.C. Asensio-S.-Manzanera), asevegma@itacyl.es (C. Asensio), baudilio@agro.uva.es (B. Herrero), jpereira@ipb.pt (J.A. Pereira), elsa@ ipb.pt (E. Ramalhosa).
}

1997; Miguel, Duarte, Venâncio, \& Tavares, 2004; Miguel et al., 2005; Miguel, Guerrero, et al., 2004), some oils showing a high 1,8-cineole content. Linalool is another major constituent in the essential oils of some populations of T. mastichina subsp. mastichina (Miguel, Duarte, et al., 2004; Miguel, Guerrero, et al., 2004; Salgueiro et al., 1997) and Thymus albicans (Salgueiro et al., 1997). Borneol is also found in significant amounts in essential oils of T. mastichina subsp. donyanae (Salgueiro et al., 1997).

Besides improving organoleptic properties of food products, spices and aromatic plants are also known to contribute to their preservation. In food industry, for example, antioxidants are very used with this end. These compounds prevent or delay oxidation reactions, in order to maintain food quality for longer periods and to extend shelf life. Some synthetic antioxidants, such as butylated hydroxyanisole (BHA), butylated hydroxytoluene (BHT) and tertiary-butylhydroquinone (TBHQ) have been used; however, the use of these synthetic antioxidants is now under discussion due to their questionable safety. Thus, it is highly desirable to find out natural antioxidants able to substitute them.

In Iberian Peninsula, several wild species of the genus Thymus have been found. Regarding T. mastichina, this is very frequent and popular in Iberian Peninsula, except in East region, Cataluña and Aragón. To our knowledge, until now no study over the antioxidant activity of essential oils and extracts of Spanish T. mastichina populations has been performed. In order to get insight on this, the 
antioxidant activity of T. mastichina populations collected in five Spanish provinces from Castilla y Léon region, was determined in the present work. In more detail, this study I) Evaluated the antioxidant activities of essential oils and methanolic extracts of twenty T. mastichina populations collected in five Spanish provinces, namely Salamanca, León, Burgos, Segovia and Soria; and II) Determined relationships between the antioxidant activities of the essential oils and methanolic extracts with their chemical composition.

\section{Material and methods}

\subsection{Plant material}

Samples of the aerial parts (leaves + flowers) of T. mastichina growing wild in Spain in five different provinces of Castilla y León, namely: Salamanca, León, Burgos, Segovia and Soria, were collected during the flowering phase (June-July 2008). At each province, four Thymus populations were collected in different localities at least $30 \mathrm{~km}$ apart. For each population 30 plants were collected in order to have a composed sample. The province, municipality, locality and altitude of the sampling sites are indicated in Table 1. At the laboratory, the plants were dried during one month in dark at room temperature $\left(24-28{ }^{\circ} \mathrm{C}\right.$ ) and relative humidity between 60 and $70 \%$.

\subsection{Chemicals and reagents}

Apigenin, caffeic acid, kaempferol, quercetin, rosmarinic acid, $p$ coumaric acid, abscisic acid, emodin, syringic acid, $\alpha$-terpinyl acetate, isoborneol, camphene, $\alpha$-phellandrene, $\alpha$-pinene, methoxysalicylic acid, hesperetin and xanthone were purchased to SigmaAldrich (St. Louis, MO, USA). Eucalyptol, linalool, camphor, terpinen-4-ol, borneol, limonene, $\beta$-pinene, luteolin and chlorogenic acid were obtained from Fluka (Steinheim, Switzerland). Gallic acid, 2,2-diphenyl-1-picrylhydrazyl (DPPH) free radical and ferric chloride $\left[\mathrm{FeCl}_{3} \cdot 6 \mathrm{H}_{2} \mathrm{O}\right]$ were of analytical grade and also supplied by Sigma-Aldrich (St. Louis, MO, USA). Folin and Ciocalteu's phenol

\section{Table 1}

Provinces, localities and altitudes of the sampling sites where Thymus mastichina populations studied in the present work were collected, as well as the oil yields and reducing powers $\left(\mathrm{EC}_{50}\right.$ expressed as $\mathrm{mg} / \mathrm{mL}$ ) of the methanolic extracts.

\begin{tabular}{lllrll}
\hline Province & Locality & Sample & $\begin{array}{c}\text { Altitude } \\
(\mathrm{m})\end{array}$ & $\begin{array}{l}\text { Oil yield } \\
(\mathrm{mL} / 100 \mathrm{~g})\end{array}$ & $\mathrm{EC}_{50}{ }^{\mathrm{b}}(\mathrm{mg} / \mathrm{mL})$ \\
\hline \multirow{2}{*}{ Salamanca } & Béjar & TM07 & 1210 & 3.13 & $5.35 \pm 0.35$ \\
& Valdemierque & TM08 & 932 & 5.31 & $5.90 \pm 0.80$ \\
& Mozarbez & TM09 & 913 & 5.39 & $3.83 \pm 0.62$ \\
& Golpejas & TM11 & 808 & 4.72 & $4.66 \pm 0.26$ \\
León & Carrocera & TM37 & 1029 & 4.06 & $4.25 \pm 0.77$ \\
& Boñar & TM43 & 1017 & 2.27 & $3.20 \pm 0.21$ \\
& Truchas & TM14 & 957 & 5.12 & $4.65 \pm 0.43$ \\
& Peranzanes & TM33 & 507 & 5.22 & $5.16 \pm 0.50$ \\
Burgos & Salas de los & TM40 & 947 & 2.60 & $4.69 \pm 0.18$ \\
& Infantes & & & & \\
& Lerma & TM39 & 828 & 3.93 & $3.66 \pm 0.19$ \\
& Oña & TM20 & 570 & -9 & $6.23 \pm 0.10$ \\
& Oña & TM32 & 550 & 4.27 & $4.26 \pm 0.27$ \\
Segovia & Villacastin & TM38 & 1056 & 5.25 & $7.24 \pm 1.15$ \\
& Riaza & TM23 & 814 & 4.89 & $3.69 \pm 0.64$ \\
& Coca & TM26 & 790 & 4.84 & $5.00 \pm 0.17$ \\
& Prádena & TM22 & 709 & 4.50 & $4.10 \pm 0.55$ \\
& Vinuesa & TM41 & 1090 & 3.43 & $5.81 \pm 0.60$ \\
& Aldealpozo & TM18 & 1061 & 5.00 & $5.59 \pm 0.76$ \\
& Almazán & TM17 & 933 & 6.48 & $4.73 \pm 0.21$ \\
& Langa de Duero & TM25 & 434 & 4.64 & $5.37 \pm 0.70$ \\
\hline
\end{tabular}

\footnotetext{
a Insufficient sample to determine essential oil yield.

b Mean $\pm \operatorname{SD}(n=6)$.
}

reagent, sodium carbonate and trichloroacetic acid (TCA) were obtained from Fluka (Steinheim, Switzerland), Panreac (Barcelona, Spain) and Merck (Darmstadt, Germany), respectively. Phosphate buffer ( $\mathrm{pH}$ 6.6) was prepared from sodium dihydrogen phosphate $\left(\mathrm{NaH}_{2} \mathrm{PO}_{4} \cdot 2 \mathrm{H}_{2} \mathrm{O}\right)$ and disodium hydrogen phosphate $\left(\mathrm{Na}_{2} \mathrm{H}-\right.$ $\mathrm{PO}_{4} \cdot 2 \mathrm{H}_{2} \mathrm{O}$ ), purchased from Merck (Darmstadt, Germany) and Panreac (Barcelona, Spain), respectively. Anhydrous sodium sulfate was also obtained from Panreac (Barcelona, Spain). Methanol was obtained from Sigma-Aldrich (St. Louis, MO, USA). Water was treated in a Milli-Q water purification system (TGI Pure Water Systems, USA).

\subsection{Essential oils isolation}

The essential oils of the T. mastichina were isolated from $180 \mathrm{~g}$ of dried material by hydrodistillation in $2 \mathrm{~L}$ of water for $150 \mathrm{~min}$, using a Clevenger-type apparatus (European Pharmacopoeia, 1996). The essential oils were dried over anhydrous sodium sulfate and stored under nitrogen in tightly closed dark vials between $-20{ }^{\circ} \mathrm{C}$ and $-30^{\circ} \mathrm{C}$ until analysis.

\subsection{Preparation of methanolic extracts}

To obtain the methanolic extracts, $0.5 \mathrm{~g}$ of each dried powder plant material ( $\leq 1200 \mu \mathrm{m}$ mesh) was mixed with $15 \mathrm{~mL}$ of petroleum ether for $24 \mathrm{~h}$ to eliminate chlorophyll and fats. After that it was filtered (Whatman filter paper No.1) and dried in an oven at $40{ }^{\circ} \mathrm{C}$ during $24 \mathrm{~h}$ and then extracted with pure methanol for $2.40 \mathrm{~h}$ in a Soxhlet apparatus (around $70^{\circ} \mathrm{C}$ ). At the end, the extracts were concentrated under vacuum at $50{ }^{\circ} \mathrm{C}$, using a rotary evaporator. All extracts were kept in the dark at $-20^{\circ} \mathrm{C}$ until further analysis. All subsequent determinations were made on triplicate.

\subsection{Determination of total phenol contents}

Total phenol contents of the extracts were estimated by a colorimetric assay based on the procedure described by Singleton and Rossi (1965) which has been frequently used in research studies (Oliveira et al., 2008; Safaei-Ghomi, Ebrahimabadi, DjafariBidgoli, \& Batooli, 2009; Sahin et al., 2004), with some modifications. Prior to the determination of total phenol contents, the extracts were redissolved in methanol. Then, $1 \mathrm{~mL}$ of sample was mixed with $1 \mathrm{~mL}$ of Folin and Ciocalteu's phenol reagent. After $3 \mathrm{~min}, 1 \mathrm{~mL}$ of saturated sodium carbonate solution was added to the mixture and the volume adjusted to $10 \mathrm{~mL}$ with distilled water. The reaction was kept in the dark for $90 \mathrm{~min}$, after which the absorbance was read at $725 \mathrm{~nm}$ (Thermo Electron Corporation Genesis 10uv Spectrophotometer). A blank without any extract was used for background subtraction. The total phenol content of each extract was determined from standard curves $(0.01-0.8 \mathrm{mmol} / \mathrm{L}$; correlation coefficients $(r)>0.99)$ prepared daily, using gallic acid as standard. Results were expressed as milligrams of gallic acid equivalents (GAEs) per gram of extract.

\subsection{Antioxidant activity}

\subsubsection{Free radical scavenging (DPPH) assay}

The radical scavenging activities of the methanolic extracts and essential oils were determined by the free radical 2,2-diphenyl-1picrylhydrazyl (DPPH) assay, according to the methodologies described by Oliveira et al. (2008) and Cao et al. (2009), respectively. The DPPH-scavenging effect was calculated as the percentage of DPPH discoloration, using the equation: \% Scavenging effect $=\left[\left(A_{\mathrm{DPPH}}-A_{\mathrm{S}}\right) / A_{\mathrm{DPPH}}\right] \times 100$, where $A_{\mathrm{S}}$ was the absorbance of the solution in which the plant extract or essential oil had been 
added at a particular level and $A_{\mathrm{DPPH}}$ was the absorbance of the DPPH solution. The extract or essential oil concentrations providing $25 \%$ inhibition $\left(\mathrm{EC}_{25}\right)$ were determined from the graphs of the scavenging effect percentages against the extract or essential oil concentrations.

\subsubsection{Reducing-power assay}

The reducing powers of the methanolic extracts and essential oils were determined by the procedure described by Berker, Güçlü, Tor, and Apak (2007) with some modifications. Briefly, various concentrations of the methanolic extracts or essential oils $(1 \mathrm{~mL})$ were mixed with $2.5 \mathrm{~mL}$ of $0.2 \mathrm{~mol} / \mathrm{L}$ phosphate buffer ( $\mathrm{pH} \mathrm{6.6)}$ and $2.5 \mathrm{~mL}$ of $1 \%(\mathrm{w} / \mathrm{v})$ solution of $\mathrm{K}_{3} \mathrm{Fe}(\mathrm{CN})_{6}$. The mixtures were incubated at $50{ }^{\circ} \mathrm{C}$ in a water bath for $20 \mathrm{~min}$. The incubated mixtures were left to cool to room temperature and $2.5 \mathrm{~mL}$ of $10 \%$ $(\mathrm{w} / \mathrm{v})$ TCA solution was added. The solutions were mixed thoroughly. Aliquots of $2.5 \mathrm{~mL}$ were withdrawn and to these, $0.5 \mathrm{~mL}$ of $0.1 \%(\mathrm{w} / \mathrm{v}) \mathrm{FeCl}_{3} \cdot 6 \mathrm{H}_{2} \mathrm{O}$ solution was added. After 2 min the absorbances of the resulting Prussian blue solutions were measured at $700 \mathrm{~nm}\left(A_{700}\right)$ against a reagent blank. The $\mathrm{EC}_{50}$ values that corresponded to the extract or essential oil concentrations which provide 0.5 of absorbance were determined from the graphs of $A_{700}$ against the correspondent extract or essential oil concentrations.

\subsection{Chromatographic analysis of the essential oils and methanolic extracts}

The identification and quantification of the volatile components present in the essential oils were carried out using an Agilent Technologies gas chromatograph, model 7890A, equipped with a Flame Ionization Detector (FID). The analysis was performed with an HP 5 Column (Agilent Technologies) $50 \mathrm{~m}$ long $\times 0.320 \mathrm{~mm}$ i.d., and $1.05 \mu \mathrm{m}$ film thickness. The temperature programme began at $50{ }^{\circ} \mathrm{C}$ and increased by $2{ }^{\circ} \mathrm{C} \min ^{-1}$ until $190{ }^{\circ} \mathrm{C}$ and then by $10{ }^{\circ} \mathrm{C} \mathrm{min}^{-1}$ until reaching $280{ }^{\circ} \mathrm{C}$ (10 min). Helium X50 PRM (Carburos metálicos) was used as carrier with a pressure of 12 psi. The injector and detector temperatures were $250{ }^{\circ} \mathrm{C}$ and $280{ }^{\circ} \mathrm{C}$, respectively. The volume of the sample injected was $1 \mu \mathrm{L}$ and the components were identified by comparison of their GC retention indices calculated by linear interpolation with those of pure compounds and of a series of $n$-alkanes $\left(C_{7}-C_{25}\right)$.

Flavonoids and organic acid contents of the methanolic extracts, previously redissolved in methanol, were determined by an Agilent Technologies 1200 series High Performance Liquid Chromatograph (HPLC), equipped with a capillary column Zorbax Eclipse XDB-C18 (4.6 m long, $150 \mathrm{~mm}$ diameter and $5 \mu \mathrm{m}$ film thickness) at $25^{\circ} \mathrm{C}$, coupled to a Diode Array Detector (DAD). Acetic acid (2\%) (A) and acetonitrile (B) were used as mobile phase, in the following ranges: $0 \min -90 \% A+10 \% \mathrm{~B} ; 10 \mathrm{~min}-78 \% \mathrm{~A}+22 \% \mathrm{~B} ; 12 \mathrm{~min}-62 \%$ $\mathrm{A}+38 \% \mathrm{~B} ; 17 \mathrm{~min}-62 \% \mathrm{~B}+38 \% \mathrm{~A}$ and $20 \mathrm{~min}-100 \% \mathrm{~B}$, at $1.2 \mathrm{~mL} /$ min. The volume of the sample injected was $20 \mu \mathrm{L}$. Compound identification was done by comparing their retention times and UV-visible spectra with their respective pure standards at a wavelength of 254,280 or $350 \mathrm{~nm}$ depending on the maximum absorption of each compound. The phenolic compounds were quantified using the external standard method and the respective calibration curve of each quantified phenolic compound.

\subsection{Statistical analysis}

The results were analyzed statistically using the SAS v.9.1.3 program. Depending on the existence of normality and homogeneity of the data, one-way analysis of variance (ANOVA), ANOVAWelch or Kruskal-Wallis Tests were performed. Pearson correlation coefficients were also determined in order to compare the antioxidant activities of the essential oils and methanolic extracts with their chemical compositions. Additionally, a Principal Component Analysis (PCA) was applied to the data sets of the methanolic extracts and essential oils of the thyme populations.

\section{Results and discussion}

3.1. Essential oil yields, total phenol contents and antioxidant activities of the methanolic extracts and essential oils of $T$. mastichina populations

The oil yields varied between 2.27 and $6.48 \mathrm{~mL} / 100 \mathrm{~g}$ (Table 1). Similar ranges of essential oil yields were obtained for the five Spanish provinces: Salamanca - 3.13-5.39; León - 2.27-5.22; Burgos - 2.60-4.27; Segovia - 4.50-5.25; and Soria - 3.43-6.48 $(\mathrm{mL} / 100 \mathrm{~g})$. Even though in each Castilla y León provinces the thyme populations were collected in different altitudes, in this work no significant correlation $(p>0.05)$ was obtained between the essential oil yields and altitude, in line with Kizil (2010).

Total phenol contents of the methanolic extracts of the twenty T. mastichina samples, varied between 2.90 and $9.15 \mathrm{mg} \mathrm{GAE} / \mathrm{g}_{\text {extract }}$ (0.29-0.915 g GAE $/ 100$ gextract $)$, as shown in Fig. 1 . The concentration ranges were the following: Salamanca $-2.90-8.17$; León 4.95-9.15; Burgos - 4.63-8.28; Segovia - 3.74-6.64; and Soria 5.48-6.05 mg GAE/gextract. Some province intra-variability was detected. For example, in Salamanca the lowest total phenol content was obtained (TM07) (2.90 mg GAE/gextract), as well as the highest third content (TM08) (8.17 mg GAE/gextract). This last sample was not statistically different to those collected in other two Castilla y León provinces, such as, the TM37 collected in León and TM39 collected in Burgos. An exception to this intra variability was observed in Soria province. In fact, the four T. mastichina populations showed very similar total phenol contents, varying between 5.48 and $6.05 \mathrm{mg} \mathrm{GAE} / \mathrm{g}_{\text {extract }}$ and not being statistically different $(p>0.05)$. However, our results were lower than those reported by Barros, Heleno, Carvalho, and Ferreira (2010) for T. mastichina extracted with methanol at $25{ }^{\circ} \mathrm{C}$ during $24 \mathrm{~h}$ (165.29 mg GAE/gextract). This difference might be due to the application in our study of a preliminary extraction with petroleum ether, probably resulting in the extraction of compounds with reducing capacity and so decreasing total phenol contents.

In relation to the antioxidant activity, the methanolic extracts and essential oils isolated in the present work were screened for their possible antioxidant activities by using two in vitro methods:

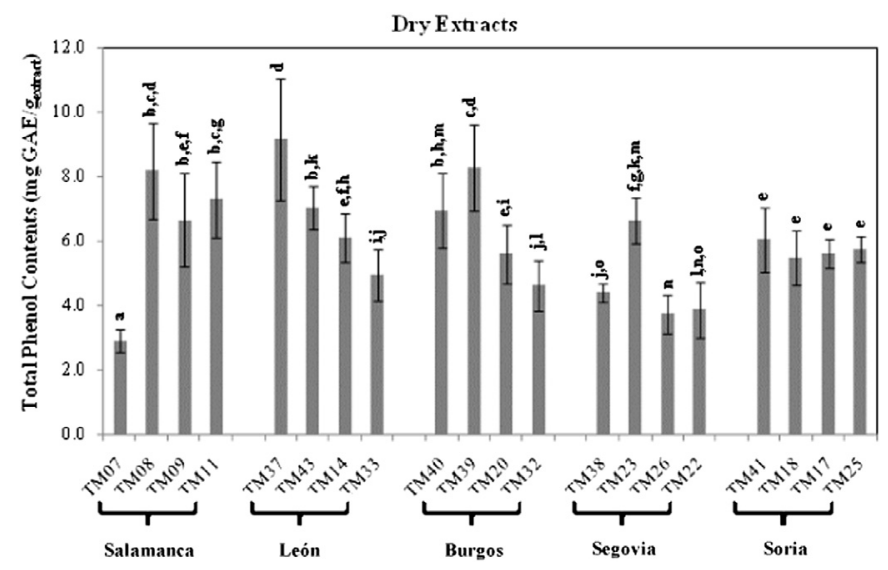

Fig. 1. Total phenol contents (mg GAE/gextract) of methanolic extracts of twenty T. mastichina populations collected in five Spanish provinces, namely, Salamanca, León, Burgos, Segovia and Soria. Results are expressed as Mean $\pm \operatorname{SD}(n=6)$. 
the inhibition of DPPH free radical and the reductive potential assays.

\subsubsection{DPPH Free radical scavenging activity}

All methanolic extracts and essential oils isolated from T. mastichina collected in Castilla y León provinces followed a similar pattern in relation to the scavenging ability on DPPH radicals. Fig. 2A shows the results obtained for the samples collected in Soria province. All methanolic extracts and essential oils followed a similar concentration-dependent pattern, increasing the scavenging activity against DPPH radical when the concentrations also increased; however, much higher DPPH radical scavenging abilities were obtained with the methanolic extracts than with the essential oils. For all methanolic extracts, inhibitions of DPPH radicals between 86.6\% (TM38 sample) and 93.9\% (TM33 sample) were determined when the highest methanolic extract concentration was used. On contrary, the essential oils presented a much lower DPPH radical-scavenging activity, varying between $30.8 \%$ (TM33 sample) and 57.7\% (TM41 sample) even when the highest concentrations were used. When analyzing Thymus pallescens and Thymus algeriensis essential oils, Hazzit et al. (2009) also stated some variability on DPPH radical scavenging abilities. Concentrations of $1.0 \mathrm{mg} / \mathrm{mL}$ of these Thymus, showed DPPH radical-scavenging activities between 59.9 and $93.4 \%$, and $6.3-53.4 \%$, respectively; however, these essential oils seemed to have a higher antioxidant potential than those analyzed in the present work, where much higher essential oil concentrations gave lower or similar DPPH radical-scavenging effect. Nevertheless, when analyzing Thymus capitatus essential oils, Bounatirou et al. (2007) obtained similar DPPH scavenging activities to those reported in the present work because scavenging effects of $5.7-17.1 \%$ and $7.6-46.6 \%$ were determined for essential oils concentrations of 100 and $250 \mathrm{mg} / \mathrm{mL}$, respectively. On contrary, Kulisic, Radonic, and Milos (2005) obtained much higher percentages of inhibition of DPPH than those reported in the present work when studying Thymus vulgaris and Thymus serpyllum essential oils, as $2 \mathrm{mg} / \mathrm{mL}$ concentrations gave scavenging activities of 91.3 and $82.0 \%$, respectively. When comparing all of these percentages with ours and taking into account the tested concentrations, the present study suggests that the isolated T. mastichina oils had weaker DPPH radical-scavenging ability than other Thymus found worldwide, such as T. vulgaris, T. pallescens, T. algeriensis or T. serpyllum. In relation to Portuguese T. mastichina populations, only one reference involving the determination of DPPH free radical scavenging activity was available (Bentes et al., 2009). In that study just one sample of essential oil was analyzed, being also stated its ineffectiveness as antioxidant.

The scavenging effects of the methanolic extracts and essential oils were further expressed as $\mathrm{EC}_{25}$ values, as represented in Fig. $2 \mathrm{~B}$. $\mathrm{A}$ higher $\mathrm{EC}_{25}$ value meant a lower antioxidant activity.

Taking into account our results, some variability was again observed on the $\mathrm{EC}_{25}$ values of each Castilla y León province. For the methanolic extracts, the values varied between 0.90 and 2.70, 1.43 to $1.93,1.45$ to $3.45,1.65$ to 2.57 and 2.11 and $2.49 \mathrm{mg} / \mathrm{mL}$ for Salamanca, León, Burgos, Segovia and Soria, respectively. In relation to the essential oils, higher values were obtained, varying from 104 to 124,86 to 241,147 to 152,78 to 191 , and 79 and $151 \mathrm{mg} / \mathrm{mL}$, for Salamanca, León, Burgos, Segovia and Soria, respectively. Similar results were reported by Safaei-Ghomi et al. (2009), when analyzing essential oils and subfractions of methanol extracts of Thymus caramanicus. In that study the polar subfraction had a much higher radical-scavenging activity, almost six and nine times higher, than the essential oil and the nonpolar subfraction, respectively.

\subsubsection{Reducing power}

This assay measures the ability of a sample to act as an electron donor that is able to convert $\mathrm{Fe}^{3+}$-ferricyanide complex to the ferrous form. The reductive potentials were only determined for the
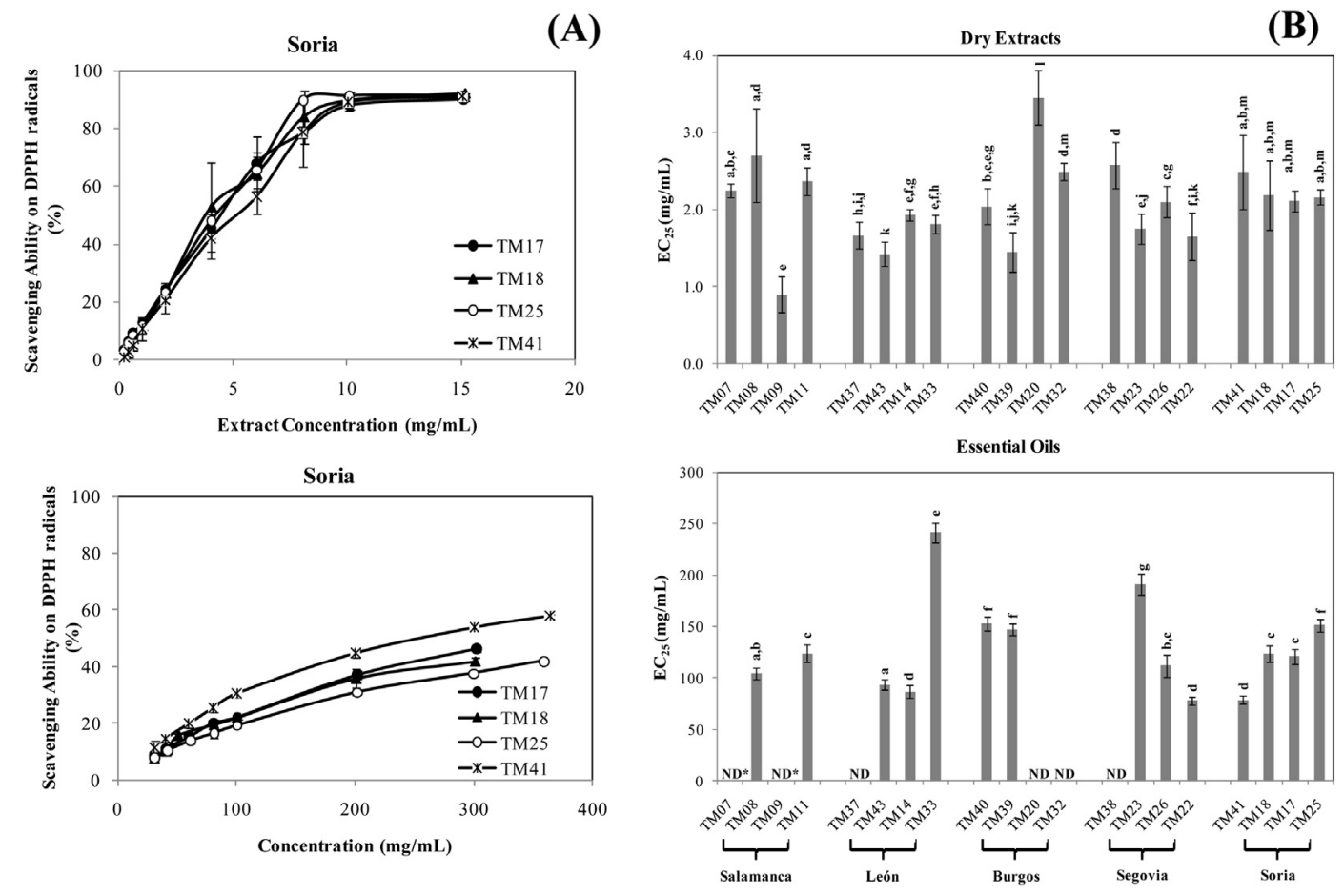

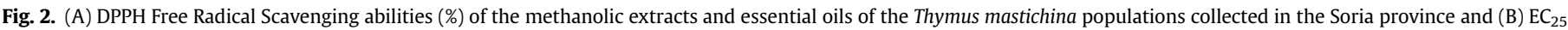

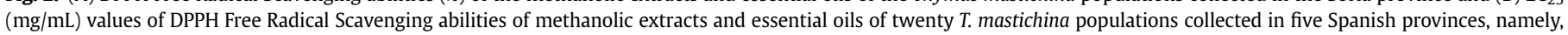
Salamanca, León, Burgos, Segovia and Soria. Results are expressed as Mean $\pm \operatorname{SD}(n=6)$. 
methanolic extracts because it was not possible to perform correctly the assay with the essential oils. This was due to the existence of two distinct phases, formed immediately after the addition of the essential oil to the phosphate buffer ( $\mathrm{pH} 6.6$ ), outcome of their different polarities. The reducing powers of the methanolic extracts of T. mastichina collected in Castilla y León provinces, increased with increasing concentrations (data not shown). When observing the results obtained for the $\mathrm{EC}_{50}$ values of the reducing power of the methanolic extracts (Table 1 ), some intra-variability was again detected between the samples collected in distinct provinces. The ranges obtained for each Castilla y León provinces were the following: Salamanca - 3.83-5.90 $\mathrm{mg} / \mathrm{mL}$; León - 3.20-5.16 mg/mL; Burgos - 3.66-6.23 mg/mL; Segovia $3.69-7.24 \mathrm{mg} / \mathrm{mL}$; and Soria $-4.73-5.81 \mathrm{mg} / \mathrm{mL}$.

When comparing our results with those reported for a Portuguese T. mastichina sample, the Spanish populations seemed to have lower reducing power. In Bentes et al. (2009) study an absorbance around 1.0 at $700 \mathrm{~nm}$ was obtained with a smaller concentration $(0.1 \mathrm{mg} / \mathrm{mL})$.

\subsection{Antioxidant activities of essential oils and methanolic extracts versus their chemical composition}

In order to better understand the antioxidant activities of the methanolic extracts and essential oils of T. mastichina populations studied in the present work, their chemical compositions were determined. The methanolic extracts were analyzed in terms of their contents in organic acids and flavonoids (Table 2), as some of these compounds possess antioxidant properties. Rosmarinic acid was the most abundant polyphenol carboxylic acid, varying between 1.70 and $9.85 \mathrm{mg} / \mathrm{g}_{\text {extract }}$, corresponding these values to TM14 (León) and TM23 (Segovia) samples, respectively. Other compounds were detected in lower but significant quantities, such as methoxysalicylic acid $(0.53-1.80 \mathrm{mg} / \mathrm{g})$, apigenin $(0.15-0.91 \mathrm{mg} /$ $\mathrm{g})$, kaempferol $(0.20-0.65 \mathrm{mg} / \mathrm{g})$ and luteolin $(0.35-1.85 \mathrm{mg} / \mathrm{g})$. Generally, it was observed that the maximums of these compounds were distributed along the Thymus populations sampled in the five provinces. The highest methoxysalicylic acid concentration was obtained for the TM43 sample, collected in León. Another sample of this province, TM14 sample, presented the highest kaempferol concentration. TM8 and TM17 samples of Salamanca and Soria provinces, respectively, were those with the highest contents in apigenin and luteolin. On contrary, other compounds were present in much lower concentrations, such as flavonol quercetin $(<0.01-$ $0.08 \mathrm{mg} / \mathrm{g}$ ) and caffeic acid $(<0.01-0.12 \mathrm{mg} / \mathrm{g})$. Furthermore, other compounds were only detected in a small number of samples (data not shown), such as: I) Coumaric acid that was only detected in two samples, TM20 and TM32, both collected in Burgos; II) Abscisic and chlorogenic acids, both detected in four samples, namely TM33, TM39, TM23, TM22 and TM43, TM33, TM23, TM22, respectively; III) Emodin in two samples, TM23 and TM26; IV) Hesperetin in TM25 sample; V) Syringic acid in seven samples - TM8, TM9, TM11, TM43, TM23, TM26 and TM22; and VI) Xanthone in TM26 sample. These results are in line with those reported by Pereira and Cardoso (2013) who observed that species of Mentha and Thymus usually comprise derivatives of caffeic acid and distinct glycosidic forms of the flavonoids luteolin, apigenin, eriodictyol and naringenin, and Gordo et al. (2012) who identified nine compounds on dichloromethane and ethanol extracts of $T$. mastichina L., including rosmarinic acid, 6-hydroxyluteolin-7-0- $\beta$-glucopyranoside, and 6hydroxyapigenin-7-O- $\beta$-glucopyranoside.

In more detail and regarding the chemical composition of the methanolic extracts of T. mastichina populations, some intravariability inside each province was again detected. The ranges of rosmarinic acid contents for the five provinces were the following: Salamanca - 2.41-4.67; León - 1.70-6.86; Burgos - 3.62-7.37; Segovia $-2.32-9.85$; and Soria $-2.08-4.78 \mathrm{mg} / \mathrm{g}$. In relation to methoxysalicylic acid, the following values were determined: Salamanca - 0.53-1.29; León - 0.89-1.80; Burgos - 0.65-0.99; Segovia $-0.66-1.43$; and Soria $-0.79-1.11 \mathrm{mg} / \mathrm{g}$. The ranges of kaempferol were equal to: Salamanca $-0.20-0.54$; León $-0.42-$ 0.65; Burgos - 0.27-0.49; Segovia - 0.33-0.42; and Soria - 0.31$0.63 \mathrm{mg} / \mathrm{g}$. In relation to luteolin, the following ranges were determined: Salamanca - 0.35-1.43; León - 0.80-1.67; Burgos 0.47-1.52; Segovia - 0.43-0.83; and Soria - 0.50-1.85 mg/g.

Regarding possible relationships between the antioxidant activities of methanolic extracts and their chemical composition, significant negative correlations were only found between $\mathrm{EC}_{25}$ values of the DPPH assay and methoxysalicylic acid $(p=0.00126)$ and between $\mathrm{EC}_{50}$ values of the Reducing Power assay and methoxysalicylic and rosmarinic acids $(p=0.00123$ and 0.0245 , respectively). These results are in line to those reported by Chizzola, Michitsch, and Franz (2008) who demonstrated that rosmarinic acid influenced the DPPH activity, as well as the ferric reducing antioxidant power (FRAP), when analyzing ethanolic extracts of T. vulgaris leaves. Thus, our results suggest that the methanolic extracts of $T$. mastichina populations with high contents in methoxysalicylic and rosmarinic acids, seemed to be able to act as antioxidants and to suppress radical chain reactions by converting free radicals to more stable products.

In relation to the composition of essential oils, the major components are shown in Table 3. It is worth noting that eucalyptol, also known as 1,8-cineole, was the main compound in all T. mastichina populations studied, varying between 56.80 and $69.60 \%$. This was expected because a high 1,8 -cineole content is a discriminatory and common feature of the essential oils of the Section Mastichina (Salgueiro et al., 1997). Linalool was the following component present in almost all samples; however, its percentage (0.62-15.7\%) was always much smaller than that of eucalyptol. In fact, only two samples, TM17 and TM25 (both of Soria), presented a linalool percentage higher than $10 \%$, equal to 13.1 and $15.7 \%$, respectively. Some monoterpene hydrocarbons,

Table 2

Major organic acids and flavonoids (mg/g of extract) found on the methanolic extracts of Thymus mastichina studied in the present work.

\begin{tabular}{|c|c|c|c|c|c|c|c|c|c|c|c|c|c|c|c|c|c|c|c|c|}
\hline & \multicolumn{4}{|c|}{ Salamanca } & \multicolumn{4}{|l|}{ León } & \multicolumn{4}{|l|}{ Burgos } & \multicolumn{4}{|c|}{ Segovia } & \multicolumn{4}{|l|}{ Soria } \\
\hline & TM 7 & TM 8 & TM 9 & TM 11 & TM 37 & TM 43 & TM 14 & TM 33 & TM 40 & TM 39 & TM 20 & TM 32 & TM 38 & TM 23 & TM 26 & TM 22 & TM 41 & TM 18 & TM 17 & TM 25 \\
\hline $\begin{array}{l}\text { Methoxysalicylic } \\
\text { acid }\end{array}$ & 0.53 & 0.73 & 1.29 & 1.01 & 0.89 & 1.80 & 1.13 & 1.33 & 0.95 & 0.99 & 0.65 & 0.79 & 0.66 & 1.23 & 0.90 & 1.43 & 1.11 & 0.79 & 0.99 & 0.87 \\
\hline Apigenin & 0.15 & 0.91 & 0.68 & 0.31 & 0.53 & 0.57 & 0.59 & 0.46 & 0.39 & 0.64 & 0.29 & 0.28 & 0.36 & 0.29 & 0.46 & 0.36 & 0.76 & 0.34 & 0.74 & 0.38 \\
\hline Caffeic acid & 0.04 & 0.12 & 0.05 & 0.05 & 0.04 & 0.05 & 0.04 & 0.03 & 0.03 & 0.05 & tr. & 0.02 & 0.03 & 0.05 & 0.03 & 0.05 & 0.04 & 0.03 & 0.03 & 0.04 \\
\hline Kaempferol & 0.20 & 0.45 & 0.54 & 0.34 & 0.42 & 0.58 & 0.65 & 0.46 & 0.27 & 0.49 & 0.27 & 0.33 & 0.33 & 0.33 & 0.42 & 0.38 & 0.63 & 0.32 & 0.54 & 0.31 \\
\hline Luteolin & 0.35 & 1.35 & 1.43 & 0.70 & 1.07 & 1.27 & 1.67 & 0.80 & 0.47 & 1.52 & 0.56 & 0.53 & 0.43 & 0.48 & 0.70 & 0.83 & 1.44 & 0.90 & 1.85 & 0.50 \\
\hline Quercetin & tr. & 0.03 & 0.03 & 0.03 & 0.03 & 0.03 & 0.03 & 0.08 & 0.02 & 0.06 & 0.03 & 0.05 & 0.07 & 0.03 & 0.07 & 0.03 & 0.05 & 0.03 & 0.05 & 0.05 \\
\hline Rosmarinic acid & 2.75 & 2.85 & 2.41 & 4.67 & 5.18 & 6.86 & 1.70 & 5.86 & 3.99 & 5.50 & 3.62 & 7.37 & 3.40 & 9.85 & 2.32 & 8.54 & 3.32 & 4.09 & 2.08 & 4.78 \\
\hline
\end{tabular}

Note: tr.- Trace amount. All of the RSD were $<10 \%(n=3)$. 


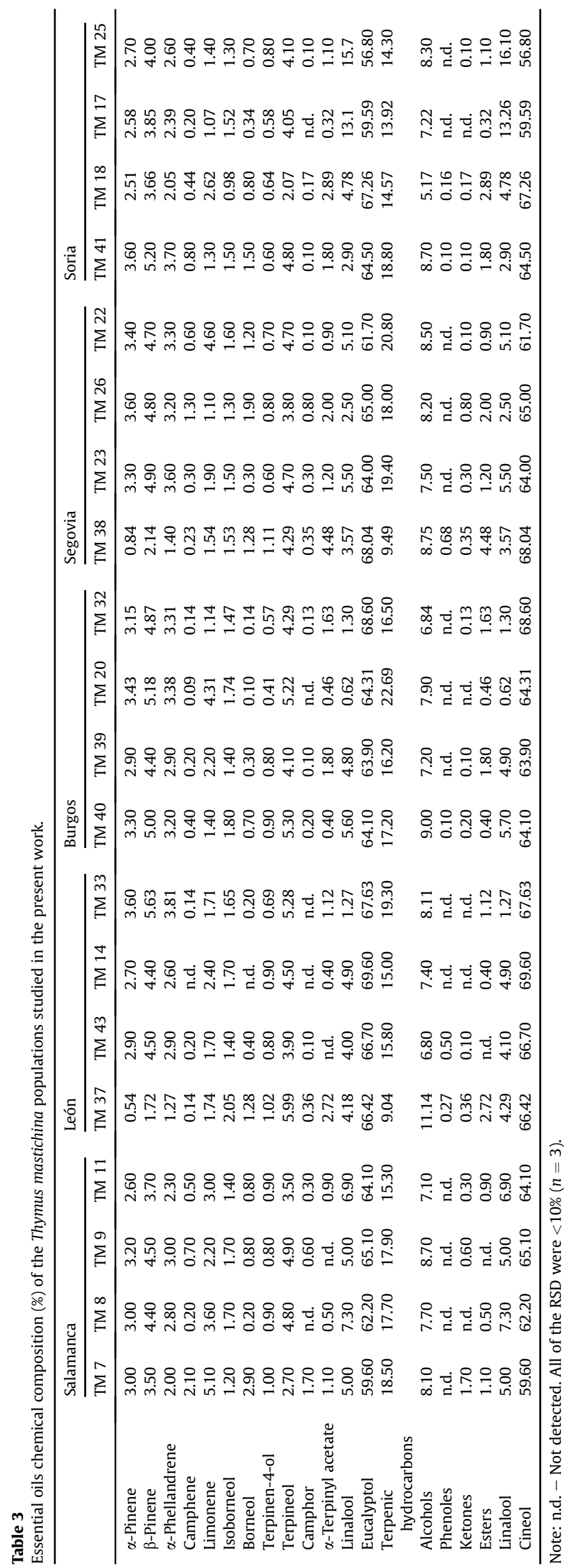

such as $\alpha$-pinene, $\beta$-pinene and camphene were detected in almost all samples, varying in the following ranges: $0.54-3.60,1.72-5.63$, and not detected to $2.10 \%$, respectively.

Taking into account these results, the main group of constituents present in T. mastichina populations studied in the present work was the cineol group, followed by the terpenic hydrocarbons. In general, all essential oils seemed to be rather like, even been extracted from T. mastichina populations collected in different provinces.

Our results were similar to those reported by Salgueiro et al. (1997) who analyzed 18 populations of T. mastichina ssp. mastichina collected in Portugal. The average of 1,8-cineole contents was equal to $53.3 \%$, close to the range determined in the present work; however, these authors found a higher range for the 1,8-cineole content (15.0-64.2\%), when compared to the present work. Our results were also identical to the findings reported by Fraternale, Giamperi, and Ricci (2003) who determined 55.5\% of 1,8-cineole and $24.5 \%$ of linalool in an essential oil isolated from plantlets of T. mastichina L. ssp. mastichina cultured in vitro, as well as to those reported for T. mastichina samples collected in the North of Portugal (58\%) (Miguel, Simões, et al., 2004) and in South of Portugal (49\%) (Miguel et al., 2005). Nevertheless, T. mastichina collected in the five Castilla y León provinces were different to the population of T. mastichina ssp. donyanae collected in Portugal by Salgueiro et al. (1997). Beyond presenting a high content of 1,8-cineole (38.4\%), this last Thymus population also had a high borneol concentration (15.3\%); however, this situation was not detected in the present work because the borneol maximum obtained in our T. mastichina populations was only equal to $2.90 \%$. The contents of 1,8 -cineole determined for the T. mastichina populations analyzed in this work were also higher than those reported for T. albicans, collected in Portugal (29.0-42.9\%) by Salgueiro et al. (1997). Nevertheless, these last samples presented a similar range of linalool, $3.2-22.0 \%$, to the determined in this work. Our T. mastichina populations also presented higher contents of 1,8-cineole than the one reported for a Portuguese T. mastichina population (44\%) analyzed by Bentes et al. (2009).

Concerning the antioxidant activity, no negative significant correlation was found between $\mathrm{EC}_{25}$ values of DPPH assay and the individual compounds determined in the essential oils. Similar results were obtained when the main classes were considered. These results might be due to the low concentrations of thymol (less than $0.7 \%$ ) (data presented as Supplemental material) determined in the essential oils. Thymol is an aromatic monoterpene, biosynthesized by the aromatization of $\gamma$-terpinene to $p$-cymene, followed by its hydroxylation (Poulose \& Croteau, 1978), being only detected in six samples. Thymol is recognized to be a strong antioxidant, and so essential oils rich in this compound, generally present the highest activities in DPPH and FRAP tests (Chizzola et al., 2008). Recently, Hazzit et al. (2009) referred that the antioxidant activity of essential oils has been attributed to the presence of phenolic constituents, especially thymol and/or carvacrol. Thus, the low thymol concentrations determined in the essential oils extracted from T. mastichina populations studied in the present work, were possibly one of the reasons that explain their low antioxidant potential. Additionally, the low contents of $\gamma$-terpinene (0.18-0.40\%), terpinolene (not detected to $0.20 \%$ ) and geraniol (0.10-0.68\%) (data presented as supplemental material) may also explain our results. In fact, some of these species have shown considerable DPPH reducing activity, as referred by Choi, Song, Ukeda, and Sawamura (2000), being some of them considered strong antioxidants (Emami, Javadi, \& Hassanzadeh, 2007). On the other hand, all T. mastichina essential oils studied in the present work presented $\alpha$-pinene (0.54-3.60\%), $\beta$-pinene (1.72-5.63\%) and limonene (1.07-5.10\%); however, as stated by Emami et al. (2007), 
these species even in the pure state, showed no or low DPPH free radical scavenging activities, reinforcing our results.

After applying a principal component analysis (data not shown), it was not possible to differentiate the methanolic extracts, as well as, the essential oils of the twenty $T$. mastichina populations by provinces, after considering the main classes of compounds or the individual ones, as well as, the values related with the antioxidant activity ( $\mathrm{EC}_{25}$ values of the $\mathrm{DPPH}$ assay and $\mathrm{EC}_{50}$ values of the reductive potential assay).

\section{Conclusions}

In conclusion, our work contributed to solve a lack of information about one plant extensively used by local populations, as food spice or medicinal herb, in terms of its antioxidant potential and chemical composition.

In detail, the methanolic extracts and essential oils of the twenty T. mastichina L. populations studied in the present work showed antioxidant properties; however, the methanolic extracts showed higher antioxidant power than the essential oils. This might be due to their chemical composition. In fact, essential oils had low contents of thymol, $\gamma$-terpinene, terpinolene and geraniol, species with considerable antioxidant activity, whereas T. mastichina methanolic extracts were rich in rosmarinic acid that is a polyphenol carboxylic acid and known by possessing antioxidant activity.

\section{Acknowledges}

The authors are grateful to the POCTEP-Programa Cooperação Transfronteiriça España-Portugal 2007-2013 for financial support through the project "Mejora de la competitividad del sector agrario de Castilla y León y Norte de Portugal a través de la innovación y el desarrollo de productos diferenciados de alto valor".

\section{Appendix A. Supplementary data}

Supplementary data related to this article can be found at http:// dx.doi.org/10.1016/j.lwt.2013.12.041

\section{References}

European Pharmacopoeia (3rd ed.) (pp. 121-122). (1996). Strasbourg, France: Council of Europe.

Barros, L., Heleno, S. A., Carvalho, A. M., \& Ferreira, I. C. F. R. (2010). Lamiaceae often used in Portuguese folk medicine as a source of powerful antioxidants: vitamins and phenolics. LWT, 43, 544-550.

Bentes, J., Miguel, M. G., Monteiro, I., Costa, M., Figueiredo, A. C., Barroso, J. G., et al. (2009). Antioxidant activities of the essential oils and extracts of Portuguese Thymbra capitata and Thymus mastichina. Italian Journal of Food Science, 21, 183-195.

Berker, K. I., Güçlü, K., Tor, I., \& Apak, R. (2007). Comparative evaluation of Fe(III) reducing power-based antioxidant capacity assays in the presence of phenanthroline, batho-phenanthroline, tripyridyltriazine (FRAP), and ferricyanide reagents. Talanta, 72, 1157-1165.

Bounatirou, S., Smiti, S., Miguel, M. G., Faleiro, L., Rejeb, M. N., Neffati, M., et al. (2007). Chemical composition, antioxidant and antibacterial activities of the essential oils isolated from Tunisian Thymus capitatus Hoff. Et Link. Food Chemistry, 105, 146-155.

Cao, L., Si, J. Y., Liu, Y., Sun, H., Jin, W., Li, Z., et al. (2009). Essential oil composition, antimicrobial and antioxidant properties of Mosla chinensis Maxim. Food Chemistry, 115, 801-805.
Chizzola, R., Michitsch, H., \& Franz, C. (2008). Antioxidative properties of Thymus vulgaris leaves: comparison of different extracts and essential oil chemotypes. Journal of Agricultural and Food Chemistry, 56, 6897-6904.

Choi, H. S., Song, H. S., Ukeda, H., \& Sawamura, M. (2000). Radical-scavenging activities of citrus essential oils and their components: detection using 1,1diphenyl-2-picrylhydrazyl. Journal of Agricultural and Food Chemistry, 48, 4156-4161.

Emami, S. A., Javadi, B., \& Hassanzadeh, M. K. (2007). Antioxidant activity of the essential oils of different parts of Juniperus communis subsp. hemisphaerica and Juniperus oblonga. Pharmaceutical Biology, 45, 769-776.

Evans, W. C. (1998). Trease and Evans' pharmacognosy. London: Baillière Tindall (Publisher).

Faleiro, M. L., Miguel, M. G., Ladeiro, F., Venâncio, F., Tavares, R., Brito, J. C., et al (2003). Antimicrobial activity of essential oils isolated from Portuguese endemic species of Thymus. Letters in Applied Microbiology, 36, 35-40.

Fraternale, D., Giamperi, L., \& Ricci, D. (2003). Chemical composition and antifungal activity of essential oil obtained from in vitro plants of Thymus mastichina L Journal of Essential Oil Research, 15, 278-281.

Gordo, J., Máximo, P., Cabrita, E., Lourenço, A., Oliva, A., Almeida, J., et al. (2012). Thymus mastichina: chemical constituents and their anti-cancer activity. Natural Product Communications, 7, 1491-1494.

Hazzit, M., Baaliouamer, A., Veríssimo, A. R., Faleiro, M. L., \& Miguel, M. G. (2009). Chemical composition and biological activities of Algerian Thymus oils. Food Chemistry, 116, 714-721.

Kizil, S. (2010). Determination of essential oil variations of Thymbra spicata var spicata L. naturally growing in the wild flora of East Mediterranean and Southeastern Anatolia regions of Turkey. Industrial Crops and Products, 32, 593-600.

Kulisic, T., Radonic, A., \& Milos, M. (2005). Antioxidant properties of thyme (Thymus vulgaris L.) and wild thyme (Thymus serpyllum L.) essential oils. Italian Journal of Food Science, 17, 315-324.

Miguel, M. G., Duarte, F. L., Venâncio, F., \& Tavares, R. (2004). Comparison of the main components of the essential oils from flowers and leaves of Thymus mastichina (L.) L. ssp mastichina collected at different regions of Portugal. Journal of Essential Oil Research, 16, 323-327.

Miguel, M. G., Falcato-Simões, M., Figueiredo, A. C., Barroso, J. M. G., Pedro, L. G., \& Carvalho, L. M. (2005). Evaluation of the antioxidant activity of Thymbra capitata, Thymus mastichina and Thymus camphoratus essential oils. Journal of Food Lipids, 12, 181-197.

Miguel, M. G., Guerrero, C., Rodrigues, H., Brito, J. C., Duarte, F., Venâncio, F., et al. (2004). Main components of the essential oils from wild Portuguese Thymus mastichina (L.) L. ssp mastichina in different developmental stages or under culture conditions. Journal of Essential Oil Research, 16, 111-114.

Miguel, G., Simões, M., Figueiredo, A. C., Barroso, J. G., Pedro, L. G., \& Carvalho, L (2004). Composition and antioxidant activities of the essential oils of Thymus caespititius, Thymus camphoratus and Thymus mastichina. Food Chemistry, 86, 183-188.

Oliveira, I., Sousa, A., Sá Morais, J., Ferreira, I. C. F. R., Bento, A., Estevinho, L. M., et al (2008). Chemical composition, and antioxidant and antimicrobial activities of three hazelnut (Corylus avellana L.) cultivars. Food and Chemical Toxicology, 46 $1801-1807$.

Pereira, O. R., \& Cardoso, S. M. (2013). Overview on Mentha and Thymus polyphenols. Current Analytical Chemistry, 9, 382-396.

Poulose, A. J., \& Croteau, R. (1978). Biosynthesis of aromatic monoterpenes: conversion of $\gamma$-terpinene to $p$-cymene and thymol in Thymus vulgaris L. Archives of Biochemistry and Biophysics, 187, 307-314.

Rasooli, I., \& Mirmostafa, S. A. (2002). Antibacterial properties of Thymus pubescens and Thymus serpyllum essential oils. Fitoterapia, 73, 244-250.

Safaei-Ghomi, J., Ebrahimabadi, A. H., Djafari-Bidgoli, \& Batooli, H. (2009). GC/MS analysis and in vitro antioxidant activity of essential oil and methanol extracts of Thymus caramanicus Jalas and its main constituent carvacrol. Food Chemistry, $115,1524-1528$.

Sahin, F., Güllüce, M., Daferera, D., Sökmen, A., Sökmen, M., Polissiou, M., et al. (2004). Biological activities of the essential oils and methanol extract of Origanum vulgare ssp. vulgare in the Eastern Anatolia region of Turkey. Food Control, 15, 549-557.

Salgueiro, L. R., Vila, R., Tomàs, X., Cañigueral, S., Proença da Cunha, A., \& Adzet, T. (1997). Composition and variability of the essential oils of Thymus species from Section mastichina from Portugal. Biochemical Systematics and Ecology, 25, 659-672.

Singleton, V. L., \& Rossi, J. A. (1965). Colorimetry of total phenolics with phosphomolybdic-phosphotungstic acid reagents. American Journal of Enology and Viticulture, 16, 144-158. 